\title{
(POST) CIVILIZATION OF FEAR
}

\begin{abstract}
The main objective of this text is to give a presentation/interpretation/comment on several philosophical authors and their philosophical scientific works, which in any direct or indirect way explore/reflect on the phenomenon of fear that controls the human unconsciousness/ sub-consciousness/ consciousness, starting from antiquity to the present day, when man lives in a (post)modern/ post-human urban civilization/ culture. The current pandemic of Covid 19 is just an occasion to start from a series of older philosophers and scientists, who explicitly or implicitly warned of the dangers of the emergence of such and similar pandemics and the occurrence of new and unforeseen human situations, in which civilization found itself as a result of the spread of deadly diseases of all kinds. The main focus is on several (four) contemporary philosophers: Giorgio Agamben, Slavoj Žižek, Lieven De Cauter, and Lars Svendsen.

In the final part of the text, instead of the usual conclusion, and with previous own incidental remarks and comments, the author gives his short critical comment on the views and philosophical/scientific predictions of the authors, who are the subject of his philosophical and scientific criticism.
\end{abstract}

Keywords: FEAR, (POST)CIVILIZATION, FUTURE, RESPONSIBILITY, CITY, CAMP, CONTROL, BARE LIFE

...our society no longer believes in anything but bare life. It is obvious that Italians are willing to sacrifice practically everything - normal living conditions, relationships and relations with other people, work, and even friendships, affections, and religious and political beliefs - because of the danger of getting sick. Bare life - and the danger of losing it - is not something that unites people, but, on the contrary, something that blinds and divides them. (Underlined by - D.S.)

(Giorgio Agamben, 2020) 
The culture of fear is a pessimistic culture. (...) Fear is undoubtedly the most important sales tool for the mass media, and it is being given more and more space. (...) In an age where the old ideologies no longer have such strong powers of motivation, fear becomes one of the most powerful agents in the political discourse. (Underlined by - D.S.)

(Lars Fr. H. Svendsen, 2010)

Although in many respects we agree with the fears of Agamben, we agree with De Cauter that they are grossly exaggerated, from the simple reason that the situation is more complex, namely systemic, and basically economic, namely capitalist/market (quite in the spirit of the words of Svendsen) (De Cauter, 2020: 24). Here, this time, unlike some other occasions and assessments of contemporary phenomena and personalities, we agree with Žižek and his opposition to Agamben "Things are much more intricate: the threat of death, also, unite people - holding the physical distance is showing respect for the other because 1 also might be a carrier of the virus. (...) We are caught in a triple crisis: health (epidemic), economic (whose impact will be strong regardless of the outcome of the epidemic), and psychological (Underlined by - D.S.) (Žižek, 2020: 74-77; Djeparoski, 2007). We would add the most essential one to this triple crisis: the crisis of the sense of a whole - created throughout history - hierarchical value system and its expediency.

At the same time, the old humanistic question again remains whether with the calming of the current pandemic (or any other crisis) people would become more moral/human (Fritzhand/Donev, D. 2020)?! Finally, Svendsen and De Cauter are a kind of bridge between Agamben and Žižek, and a spiritual constant of what is often called the need for humanistic optimism as an act of resistance and modus vivendi/ élan vital, which in their words is summed up in a reliable "common" conclusion: "However, it is impossible for our lives to be completely controlled" (Svendsen, 2010: 67), and "the third millennium must not become an experiment with the future. Humanity must do everything in its power to prevent this invisible catastrophe" (De Cauter, 2020: 16) (Underlined by - D.S.).

Although we find the premises of the new philosophy/ethics of medicine, i.e. today already sociobiology, bioethics, and biopolitics, among older authors (Jean Bernard, François Jacob, Hans Jonas, and many others), the antithesis of the views of Agamben and Žižek, and the analyzes of Svendsen and De Cauter, will be a reference background further in this short essay. ${ }^{1}$ That does not mean that we agree with all "diagnoses" of Svendsen, but

${ }^{1}$ Unlike some of our other texts, on this occasion we will not problematize the relations of meaning of the phrases: "philosophy of fear", " culture of fear" and "civilization of fear", and for the sake of simplicity we will consider them almost identical, although they are, of course, far from identical. All the more so that the phenomenon of fear may be subject to analysis of a whole range of sciences and transdiscoursive scientific dis- 
it must be admitted to him that with the chronology of analyses of fear among many philosophers and thinkers he succeeded to convince us that the phenomenon of fear is not at all a marginal phenomenon when in a direct or indirect way it has attracted the attention of philosophers and scientists for centuries, starting with Thucydides, Plato and Aristotle, and through Aquinas, Beme, Montaigne, Hobbes, Burke, Kant, Hegel, Schelling, Kierkegaard, James, up to Cassirer, Heidegger, Arendt, Benjamin, Sartre, Freud, Fromm, Foucault and a whole range of other modern/contemporary thinkers with a sociological and psychological intellectual vocation (Honderich, T., 1995; Regenbogen, A.,/Meyer, U., 1998). It turns out that there is no philosopher (especially artist!) who has not spoken at least something, and in any art articulated "language" (verbal/auditory/visual/film) about the phenomenon of fear (eg. the expression of fear in the famous painting "the Scream" by Edvard Munch). Here above all, the fear of death - more or less is present in all of us, were we aware of it or not - and then the fear of God/God's punishment, the fear of the authorities, of the unknown, strangers, foreigners (foreign traditions), different from us; then fear of war, of changes, fear of the new (new technologies, artificial intelligence, radiation from telecommunication devices), fear of the future, a range of environmental fears, contaminated food, pesticides, radiation, experiments with human genes, etc. (Simonovska, 2006; Davchev, 2020; Ćulafkova, 2007:522) .

That the phenomenon of (ir)rational fear (of everything) is already a chronic condition/obsession of the spirit (cultural phenomenon) is proved by the fact that we are already talking about a theory of fear, especially within the literature theory (Ćulafkova, 2007: 522). It is also proven by the series of data that Svendsen gives us in his inspiring and easy-to-read essays. In one he cites a 2005 study that was expected to find out what people in today's civilization are afraid of, and in which "people are asked to value a wide selection of ninety potential dangers, from jogging and cosmetics to terrorism and vaccines" (Underlined by - D.S.) (Svendsen, 2010: 11-20). As we can see, the phenomenon of vaccine(-ation) (not even to mention "terrorism", for example, the understanding of it by the judiciary system in Macedonia), and the controversy surrounding it/them, are nothing new. It dates back to at least the time of the AIDS pandemic (HIV), which, according to medical experts, "should" have infected at least 200,000 people in Macedonia. Not to mention the Chernobyl accident, which occurred at about the same time (April 26, 1986), and when, for fear of irradiation of the fetus - despite the (dis)assurance of radiologists of an extremely minimal danger - unfortunately, more than 2000 Macedonian women had an abortion (namely, the radiologists responsibly claimed that the measured radiation com-

ciplines: starting from biology and medicine, and ending with psychology, sociology, political science, philosophy/aesthetics/ethics, culturology, theory of literature, etc. (Filipović, 1989; Ćulafkova, 2007:522; Djeparoski, 2020). 
ing from Chernobyl to Macedonia was 100 times less than the radiation emitted by ordinary X-rays!). Since then, many "madnesses" have occurred, including the "cow madness", not to mention the wide range of fevers, flues, and viruses, starting with the "Spanish fever" which took between fifty to one hundred million lives, then the "Hong Kong", "Avian" and "Swine" flu, or Variola vera from the early '80s, which, according to some biomedical experts, includes Covid 19, and which has reached, as we see, an unprecedented number of infected people worldwide. So, a further listing of fears could be infinite for us (Svendsen, 2010).

Among others, we return to the already mentioned Hegel, because Svendsen starts from him. According to his interpretations, when Hegel describes human habits (physical and mental/cognitive), he is actually talking about fears, which, when constantly repeated, become almost our "second nature", i.e. culture (Svendsen, 2010: 11-47). And when we are dealing with culture then we are dealing with art/aesthetics, and in the context of the aesthetic category sublime, then we are talking about experiencing "a kind of terrible horror" caused by the grandiose natural objects due to their true immensity, i.e. they cause awe (Djeparoski, 2020: 179-189). Although the "habit" as a gnoseological process/problem has been known since Hume, in the formulation of his main hypothesis Svendsen starts exactly from Hegel: "My hypothesis is that fear is about to become such a habit...

"By this, I am not so much thinking of strong, overwhelming fear but rather of what could be described as low-intensity fear. (...) It seems that we habitually focus on what is potentially dangerous in everything we encounter in life. We ought to distinguish between fear as a general disposition and fear as an actual emotion. (...) In studies of fear, the emotionally intense variant is the type most often emphasized. The type of fear that is predominant in our culture is, as mentioned, more what could be referred to as a low-intensity fear, a fear that surrounds us and forms a backdrop of our experiences and interpretations of the world". (Underlined by - D.S.)

(Svendsen, 2010: 46-47)

With these generalizations of Svendsen, we can without exaggeration conclude that the psychosis of fear has become a mass/global phenomenon, an almost global "worldview" or a new "ideology", as evidenced by the pandemic of Covid 19, i.e. that by exaggerating the danger of contagion - which is undoubtedly great - it has led to the successful globalization of fear as a new political manipulation. (Žižek, 2020: 13-20) So "fear of low intensity" in the meantime has grown into an extensive/panic fear of high intensity, using primarily the digital mass media for spreading panic, awe, astonishment, bewilderment, intimidation, (mis)information, total media cacophony, and disorientation/distrust in science/medicine, given the opposing "expert" opinions, all of which are used in the interest of new geopolitical regrouping of the world power, and now new biopolitical restructuring (Agamben, 2018: 224; Ska- 
lovski, 2018). But when we are still with Svendsen it is worth noting that his analysis of fear continues with the analysis of related terms, such as the term "risk", but in which context Svendsen puts Jonas' "Heuristic of fear", which, given that we are sufficiently competent connoisseurs of Jonas, we claim that Svendsen misunderstood this phrase of Jonas. Namely, it refers to the fear that implies moral responsibility of the people of today for the fate of the people in/ of the future, i.e. the endangered/uncertain/catastrophic future of our generations, and Jonas rarely or does not mention at all the risk as such, because his ethics of responsibility has a different social/political/economic and theoretical/ theological/philosophical, namely ethical provenance (Svendsen, 2010: 68-69; Jonas, 1978; Skalovski, 1995/2005).

In his provisional conclusions/theses, Agamben starts exactly from the (geo)political level, i.e. from the fundamental character of the sovereign power and its extension to the totality of human life. Unable in this small space (and there is no need!) to elaborate on his complex philosophical performances (starting with Aristotle and ending with Foucault), we will rely on his concluding words, which clearly and explicitly reveal Foucault's great influence, who in the last years of his life had focused his research more and more to "what he defined as biopolitics, or to the growing implication of the natural life of man in the mechanisms and calculations of power" (Agamben, 2014:147).

His first conclusion is: "The original political relation is the ban (the state of exception as a zone of indistinction between outside and inside, exclusion and inclusion"). With this conclusion, Agamben puts into question every theory of the contractual origin of state power and, along with it, every attempt to ground political communities in something like a "belonging," whether it is founded on popular, national, religious, or any other identity (Agamben, 2014:223) (Underlined by - D.S.).

His second conclusion is: "The fundamental activity of sovereign power is the production of bare life as an originary political element and as a threshold of articulation between nature and culture, zoē and bios", namely bios as a status of social living, and zoe as a status of ordinary/superficially physical/bodily existence which is outside the law, and in which an increasing number of people are pursued, and who are already without any rights, and who are governed by the logic of the camp. This meta-anthropological/holistic conclusion of Agamben ends in a kind of retroactive value judgment for all Western civilization/ culture, i.e. that Western politics was/is biopolitics from the very beginning, and that every attempt to found political liberties in the rights of the citizen is (was), therefore, in vain (Agamben, 2014: 223; De Cauter, 2020: 24).

Agamben's third conclusion is: "Today it is not the city but rather the camp that is the fundamental biopolitical paradigm of the West." This means that this, third conclusion, is the most important/the most essential, given that it...

"...throws a sinister light on the models by which social science, sociology, urban studies, and architecture today are trying to conceive 
and organize the public space of the world's cities without any clear awareness that at their very center lies the same bare life (even if it has been transformed and rendered apparently more human) that defined the biopolitics of the great totalitarian states of the twentieth century" (Underlined by - D.S.).

(Agamben, 2014: 223-224)

Needless to say, in such "camp" urban circumstances, nothing remains of what modern philosophy and the social sciences imagined/constituted as an individual/collective emancipated entity. This regardless of whether these sciences/philosophies have a more Hegelian-Marxist (mostly "collectivist/general") or more Nietzsche-Kierkegaard (mostly "individualist/single") historicistic provenance, i.e. as a history of class struggles of "organized subjective forces", i.e. a history of the struggle for political power/authority (Lukács, 1977; Solunchev, 2020: 48-49). Of course, both provenances date back to ancient times, namely Aristotle.

In the syntagm "bare life," "bare" corresponds to the Greek haplōs, the term by which the antic philosophia prima (or ontology), primarily with Aristotle, aspired to define pure Being. The isolation of the sphere of pure Being, which in Agamben's view constitutes the fundamental activity of Western metaphysics, is not without analogies with the isolation of bare life in the realm of Western politics. In other words, what constitutes man as a thinking animal has its exact counterpart in what constitutes him as a political animal. Agamben puts the question for the link/relation between these two constitutive processes (metaphysics and politics), which, themselves insufficiently clear/determinate, namely "empty", and each isolated/closed (some philosophers would say "alienated") in their proper element, simultaneously run up against an unthinkable limit, which causes stupor, astonishment and finally - fear for the bare life (Agamben 2014: 224). If said with today's, contemporary ancient philosophical language, eg. Marxist, we could simply say that it is about the relation theory๑practice, or more precisely - metaphysical theory@social practice (Habermas, 1980).

Finally, in order to avoid omissions in a selective citation, we convey Agamben's definitive/final conclusion, or "answer," in integral form, mainly because his words are in fact a general critical judgment that Agamben points to the West as a cultural/civilized world with a history of three thousand years, which turns his "theory" of fear into a general retroactive critique of Western civilization and culture in general.

"Yet precisely these two empty and indeterminate concepts seem to safeguard the keys to die historic-political destiny of the West. And it may be that only if we are able to decipher the political meaning of pure Being will we be able to master the bare life that expresses our subjection to political power, just as it may be, 
inversely, that only if we understand the theoretical implications of bare life will we be able to solve the enigma of ontology. Brought to the limit of pure Being, metaphysics (thought) passes over into politics (into reality), just as on the threshold of bare life, politics steps beyond itself into theory".

(Agamben, 2014:224-225)

Moving on to Žižek, we go deep into the current situation we live in every day in the (co)presence of the Coronavirus Covid 19. From the very beginning, we hinted that our attitude of agreeing or disagreeing with some of Zižek's assessments depends on how principled/ consistent he remains in his fierce criticism of capitalism, of which we are all more or less victims, and we cannot escape it even in a dream, at least in his estimation, and which critique crowned him with the halo of "the most dangerous philosopher of the West." However, this halo, according to our and not only our critical judgment, Žižek deserves less and less, primarily because of a series of nonsense and fabrications (not to say harder words) that he has literally started saying "off the cuff" in the last few years (Žižek, 2020: 31-34). But we will leave them aside for another occasion, and we will focus on those analyzes/diagnoses/prognoses of his that deserve serious attention.

This refers primarily to problems and chaotic/nightmarish /"obscure" situations in which the world has found itself with the pandemic of Covid 19, but with the important note that in this case, as the famous wise saying goes, "there is a system in chaos" (from which the modern social theory of chaos is derived, among others), and namely that is the point: the purpose of this "hunting in the dark" is to create a new complex/ sophisticated/ camouflaged system/order of global control, manipulation, domination, exploitation, and consumption. As Zižek and a number of other analysts/critics of international capitalism/ globalism say, this control over our lives, primarily digital, is mostly exercised by transnational corporations, i.e. "the big companies and the secret government agencies that know us better than we know ourselves and use this knowledge to control and manipulate us" (Žižek, 2020: 46). This is the main thing, and everything else that Žižek talks about, in some places even contradictory, unprincipled and chaotic, are just more or less epiphenomena/by-products, as this corporate/global power, in conjunction with "fascism with a smiling face" (Fromm) is the creator/producer of "our" system of economic, political, ideological and a whole range of other "cultural" values, creating a permanent sense of depression, pessimism, hopelessness, fatality, absurdity, nonsense, namely "causing constant fear and a sense of fragility in our lives" (Žižek, 2020: 46-47; Fromm, 1980) (Underlined by - D.S.).

We would add to these conclusions of Žižek, only after a year from it, the benefits and profits are announced through the media (in billions of dollars and euros) of the already rich who became even richer, and the already poor even poorer, this time abused/destroyed by the military profiteers (because this is a hybrid war!), and all others who have an interest/benefit/profit from the 
mass contagion, mass mortality and mass treatment/ vaccination across the Planet (Habermas, 1975). This is regardless of whether these profiteers of all colors are often called the pharmacomafia, or with any other immoral, criminogenic/ criminal attribute (MacIntyre, 1998). A similar valuable/critical judgment could be expressed for the whole global/capitalist civilization, which is not in crisis, but at its end, which means the urgent need to change/replace it, as an "immodest" value system, with a more "modest" system and the "lower" set anthropocentric/self-centered/"individualistic" goals (in the spirit of generality/Allgemeinheit in Hegel and the Marxists), and it is entirely consistent with the findings of a series of contemporary philosophers of different philosophical/ideological provenance, starting with Fromm, Jonas and a range of others, and ending with Žižek and a range of others. It is clear, Žižek believes, that this capitalism is "catastrophic capitalism" and "tyranny of the culture of the brand" (Noami Klein), and that the pandemic is only the cause for some radical/general critical conclusions about the meaning/justification/"logic" -raison d être - of the global world/capitalist order/system. Namely, ...

"We will have to learn to think outside the coordinates of the stock market and profit and simply find another way to produce and allocate the necessary resources. If the authorities find out that a company is stockpiling millions of masks, waiting for the right moment to sell them, there should be no negotiations with that company, but the masks should simply be confiscated. (...) Will the epidemic be reduced to just one more chapter in that long sad story that Noami Klein calls "catastrophic capitalism" or will it result in a new better balanced, and perhaps a more modest world order?" (Underlined by - D.S.)

\section{(Žižek, 2020: 73-79)}

In the spirit and "words" of Žižek and Noami Klein we would add: Probably each ordinary/average person (woman/man) as a resident, settled at any point on the planet Earth, and endowed with average intelligence and common sense, sees it clearly already that it can no longer go on like this: "It was this far", says the famous old Macedonian proverb. Perhaps it is no longer important at all (does anyone care?!) what would that possible new socio-political order/system be called: socialist, communist, military, egalitarian, totalitarian, dictatorial, tyrannical, despotic, or "Chinese" "Soviet", "hybrid", or (non)liberal, (un)democratic, leftist, rightist, progressive, conservative, etc. listing all the ideological and political attributes known so far, as Žižek does (Žižek, 2020). Perhaps it becomes clear that now it is no longer a struggle for progress and prosperity, but a struggle for survival. Progress is over, we are fighting for survival (Allen, 2016). Perhaps it becomes definitely clear that what matters most is whether this new (and maybe old as an idea?!) system - whatever we call it will enable/ ensure the survival of human civilization/ race or not (Honet, 2019). Probably it becomes clear that the struggle for survival will take place beyond 
all existing systems of philosophical thinking and practical action (Djeparoski, 2000). It is probably clear that there is an urgent need to create new systems of thinking and acting, a new theory/ theories of value systems (social, cultural, political), which will be beyond the existing/past, and which namely led us to an unfavorable and extremely dangerous situation for the survival of civilization (Kosik, 2007; Dugin, 2009). Žižek is right here when he concludes that we have been deaf to the words of those scientists/ philosophers/ artists who for decades warned that the existing value system - conventionally called "Western" - not only became irrational, but that it will bring us to the brink of a catastrophe from which there will be no escape (Djeparoski, 2012). If "humanity is threatened by thirst" (Council on foreign relations, 2021), then man is not interested in whether there is water on Mars, or what is someone's program/ "investment" for/in "conquering" space, but he has a rational fear of having healthy (and not technical!) water for him and his children in the home well/ spring / local water supply. Perhaps it is clear that man is in a hangover/ awakening/ "sobriety" from the cosmic dream/ drunkenness/ ecstasy/ trance/ illusion, and that a hard/ painful "landing" awaits his Icarus' "flight in place", i.e. "liberation", among others, from the myth of technology. In other words: the "dream" is over, we are going back to history (Stefanovski, 2002; Davchev, 2020; Milutinović, 2018: 41).

We have left the modern Belgian philosopher/ esthetician/ art historian and analyst of architectural discourse, Lieven De Cauter, to be the last in our essay, even though he is not the latest (2004/2020), but because he sub-sums/ synthesizes the previous ones, especially Agamben, in his work "The Capsular Civilization", in which he sees in architecture/ urban the new forms of voluntary slavery and captivity (Fromm would say "escape from freedom") (De Cauter, 2004/2020). De Cauter himself admits that his intention was to write a book on "city politics", but that the phrase is pleonasm because the city is always a political subject, even when it is the starting point of the aesthetics of the city, which means that he wanted to write a book on the political aesthetics of the modern city. However, De Cauter admits, the emergence of cities/ urban agglomerations protected by barbed wire walls has turned its original intention into a philosophical/ theoretical reflection of society, which needs to build these barbed-wire walls, so that the research led to the formation of the image of society, namely "the capsular civilization" as a macro perspective of permanent catastrophe and new imperial world order, for the analysis of which De Cauter uses the analysis of a series of predecessors, starting with Benjamin and ending with Virilio. In the end, De Cauter concludes, meanwhile the "age of fear" has taken over, which all the themes of his book (the place of utopia in the age of globalization, politics as a skill for the "good life", etc.) has made them even more relevant and urgent, and brought into touch and complementarity with Agamben and his reflections, which we have already summarized, and with which De Cauter agrees, too: 
"In the light of the generic city the Declaration of CIAM (Congres internationaux d'architecture moderne) from 1951 takes on a prophetic tone: "If new cities are built without a core, they will never become more than just camps." (...) Perhaps Agamben, despite the seemingly gross exaggeration, is right when he claims that the paradigm of modern politics is not the city, but the camp". (Underlined by - D.S.)

(De Cauter, 2020: 24)

After these words and facts (the CIAM Declaration of 1951), for us, as well as for Žižek, among others, the crucial question arises: Why the "prophetic tone" of this Declaration in the past exactly 70 years has not attracted much attention to the world intellectual and wider world public?! With this, we again return to the words of Žižek: "What is wrong with our system, so we found ourselves unprepared for the catastrophe that befell us, despite the fact that scientists have been warning us for years" (Underlined by - D.S.) (Žižek, 2020: 11; Djeparoski, 2000)? Haber-mas's statement from 40 years ago that we hurried irresponsibly when "we threw the philosophies of history in the old iron" without offering new/ more solid theories that would clarify and predict the practical consequences of scientific-technological progress, and perhaps it is clear that the "natural" occurrence of the Covid 19 pandemic is precisely the product of genetic experimental engineering that successfully/ hybridly combines these natural elements and globally "put on the market" with the now obvious technocratic/ profitable geopolitical/ biopolitical strategic interest (Habermas, 1980: 342; Habermas, 1975). A weak/ belated consolation is that in the last few years we are returning from "self-oblivion" (Heidegger) some prominent proto-Marxists/ proto-Freudians, such as Erich Fromm, who is recently returning "In fashion". However and whatsoever, this time we hope that him and a range of other ingenious thinkers from the recent and distant past, to name them "scientists/ philosophers futurists", we will not ignore, underestimate or "ridicule them because we do not understand them", as the ingenious Johann Wolfgang von Goethe said, or that they will not pass like any current/ short-lived "fashion trend" (Fromm, 1980; Skalovski, 2020; Allen, 2016; Gete, 1979: 123).

Or we thought that "the phenomenology of fear" is only a fruit of an anxious poetic imagination and apocalyptic scenario of a popular cultural and entertaining science fiction TV series, and not a warning of serious/ responsible artists, scientists, philosophers, theologians, and other intellectuals who did not succumb to the temptation of conformism/ opportunism of the spirit, which proved to be fatal/ self-destructive. For our own consolation and intellectual "pure conscience" we can only remind that we, namely our intellectual smallness, with the help of other authorities (from Charles Jenks and Paul Virilio and many others to Boris Chipan, Ilija Aceski, and many others), "touched" this "prophetic" topic in the first decade of the $21^{\text {st }}$ century, and on the occasion of the city of Skopje and its suburbs/ agglomeration, and their multidimensional/ multiple and ambiguous (co)relation with other urban and rural parts/ areas of naturally and culturally beautiful Macedonia. This especially refers to the years/ 
decades after the earthquake in 1963, as a key/ turning point/ year in the development of the City (Skopje) and the Republic (Macedonia) in every respect: starting from the ecological, technological and economic, and ending with the cultural and the political (Chipan, 1986; Virilio, 2003; Skalovski, 2010: 27-37).

\section{Instead of a comment, or the need for a new theory of the (ir)rationality of fear}

We assume that the reader's impression of this short essay will be that we have missed the point and that we have gathered too many inconsistent predictions, and that our attempt has ended in a failed and syncretic/ eclectic fusion of fundamentally incompatible and too different theories/ projections for the future, and such as those of Agamben, Žižek, De Cauter, and Svendsen. However, the careful reader cannot "miss" the conclusion that, in essence, they are all talking about the same thing, i.e. for the same "fear," which in Kundera's language we might call "the fear of the unbearable lightness of reckless/ gullible prediction". This is all the more so since they themselves quote and refer to each other, and regardless of the differences in the degree of optimism/ pessimism i.e. utopianism/ dystopianism with which they look to the future of what we colloquially call "(post)civilization of fear", i.e. the most plastically expressed in the words of De Cauter, "capsular civilization", in which we voluntary become captives/ slaves, among other things, of architecture and urbanism.

Ultimately, but not least important, the relevant question remains, which this time starts from the logic of pars pro toto, i.e. that the fear of the deadly pandemic in one, the most developed/ richest part of humanity entails the expansion of the fear of doom over the totality of the whole world society, namely the whole civilization as such?! Of course, if it does not turn out/ reveal/ prove that in the end, everything was a pre-arranged/ planned scenario and a bluff in someone's profit/ geopolitical/ biopolitical interest?! In other words, is it just a new (post)ideological/ neoliberal "mantra", "trick", i.e. this time the "ideology" of fear, which seeks to impose its partial fear on all other parts of the world (the West and the Rest), which in turn is the result of the efforts to "westernize" the whole world, as shown by the analyzes and forecasts of Alexander Zinoviev and a range of other "non-Western" theorists and forecasters (Zinoviev, 2002; Skalovski, 2019: 567-577; Stojanov, 2021; Sarkanjac, 1992; Milutinović, 2008)?! Of course, this is a new and complex "Pandora' $\mathrm{s}$ " topic, which, as things go with the controversy surrounding the pandemic - above all on the interference line freedom $\leftrightarrow$ coercion - will still be provocative for philosophical, artistic and scientific/ critical thought/ reflection, and which, as such, we will leave for some next occasion. This is primarily because we are far from having enough "experiential" material (the pandemic "lasts" for only two years) to draw any scientific/ philosophical conclusions and predictions from a position of historical distance. In the context of such philosophical predictions, made/ started in the past, we must leave them for another occasion. This also refers to the need for 
analysis from a number of other aspects: starting with the global relationship and the global division of labor on the East-West line, and then North-South, and then the global class-social, especially gender/ feminist aspect (eg. prison slave female labor), which irresistibly reminds/ resembles the "camp" one we analyzed; in a word, the old and the new global relations of power, manipulation, domination, misuse and ruthless exploitation (read: new world slavery placed in camps!) (Simonovska/ Petkovska, 2019: 543-551).

However, for all these reasons, and at least for now due to the current pandemic, we are inclined to treat the phenomenon of fear as a predominantly and still dominantly psychological phenomenon. Hence, although psychology is not our primary professional orientation, at the end of our essay we decided on well-known/ popular/ laic "definitions" of fear, only in the form of aphorisms/ slogans/ folk sayings/ wisdom (including vulgar ones), which means without any ambitions/ pretensions for expertise, competence, and scientific/ cultural validity. If nothing else, these folklore/ jargon sayings are "witty", "relaxing", yet with a dose of wisdom/ rational precaution/ responsibility and measured concern/ worry, which are perhaps the most useful/ needed at a time of apparent global danger of raising mass and unnecessary panic (Donev, 2018: 165-174; Simonovska/Skalovski, 2012: 137-139). We hope/ believe that the future will show/ prove that we were right and that we have not underestimated the real danger of this certainly very dangerous/ deadly disease, and even more so that such dangerous pandemics have existed earlier in history, and which took millions of lives. Still, from a "serious" and philosophical point of view, it is obvious that there will be a maximum relativization/ reinterpretation of György Lukács's famous study "Destruction of the Mind" (on the occasion of Nazism/ fascism), which at the time was greeted by philosophical critics "with a knife" and with indignity. His then critique of (ir)rationalism, whose manifestations were located by the ingenious Lukács in Schelling's philosophy, today - when we live in a civilization we can colloquially call "(post)-civilization" - the same critique is read and interpreted with different "eyes" (Lukač, 1966).

For if for many years/ decades/ centuries (if we count from Nietzsche and Marx) we speak of the superhuman, the transhuman or the new man (in socialism), as a rational prediction/ construct/ product of technological civilization, and if we conclude that we have become posthumans, then logically it follows that we can talk about something like "postcivilization" (Hiles, 2003; Djeparoski, 2018: 10). In the present historical context of (ir)rationality of fear of the pandemic as a mental/spiritual content of the resident of "post-civilized city" this/ such critique is yet to gain its relevance and critical/ philosophical validity in the overall efforts of philosophical/ scientific discourse to interpret and predict/ project the future, but also in its own positive or negative contribution/ share and responsibility in the creation of human light, or dark future (Lukač, 1966). In fact, as always, what will be ours, and the future of our children, depends mostly on ourselves, today's living beings and our (un)smart ideas and actions, and in the "prediction" of the future - as good/ beautiful or 
as bad/ ugly - Lord-God can help us a little if we ourselves, as disappointed idealists/ utopians, do not know/ do not want/ do not have an active moral and political will to help ourselves, and thus enlighten/ beautify our future, ourselves (Kocarev, (a), 2021:2; Djeparoski, 2012). It is not from God - it is up to us. The slogans "God help us", "Good luck", "Cheers" are not enough. We wait in vain for salvation only from God if we ourselves do not know/ are unable to help/ save ourselves.

So, as we have already announced, for the relatively "optimistic" end of our relatively "pessimistic", "terrible" essay on fear, we enclose the following few popular proverbs that we have in the rich domestic folklore and traditional culture, and we appreciate that the sense and meaning are in the wider context of the fear of the pandemic, i.e. of fear "as such".

Wise fear begets care! / Better safe than sorry! ${ }^{2^{*}} /$ No cat drinks covered milk!

Everyone spits on a naked ass! / A deserted village! / God be with us!

\footnotetext{
${ }^{2}$ At the very beginning of this pandemic, about a year ago, a dear neighbor literally told me the following: "My neighbor, I have never been a panicker, but just in case I bought 20 kilos of flour for home". This tragicomic statement perhaps expresses all the (ir)rationality and "ambivalence" of the feeling of fear in the most illustrative way?!
} 


\section{LITERATURE}

Агамбен, Џ઼., (2014), „Ноmo Sacer - суверената моќ и годиот живот“, Сигмапрес, Скопје.

Agamben, G., (2010), „Profanacije“, Rende, Beograd.

Allen, A., (2016), The End of Progress: Decolonizing the normative foundations of Critical theory, New York: Columbia University Press.

Арент, Х., (2013), „Изворите на тоталитаризмот“, Култура, Скопје.

Ацески, И., (2003), „Човекот и градот“, Скопје.

Bernar, Ž., (1975), „Veličina i iskušenja medicine“, Nolit, Beograd.

Вирилио, П., (2003), „Сајберсвет, политика на најлошото“, Еин-Соф: Алеф, Скопје.

Gete, J.V., (1979), „Faust“, Prvi deo (Dvojezično izdanje), Nolit, Beograd.

Давчев, В., (2020), „Треба ли да стравуваме од вештачката интелигенција филозофски дилеми“,(воракопис).

De Kauter, L., (2020), „Kapsularna civilizacija: o gradu u dobi straha“, Futura publikacije, Novi Sad.

Djeparoski, I., (2012), „The Salvation of Europe is (Found) in Beauty?" , Cultura, Vol. II, No 3, 2012, pp. 121-126.

Донев, Д., (2018), „Вовед во етиката“, Скопје: УКИМ.

Дугин, А., (2009), „Четврта политичка теорија“, Амфора, Санкт-Петербург.

Жижек, С., (2020) „Пандемија! - Ковид-19 го тресе светот“, Libris, Скопје.

Зиновјев, А., (2002), „Запад: феномен западњаштва“, Наш Дом/Age D'Homme, Beograd-Lausanne.

Jakob, F., (1978), „Logika živog“, Nolit, Beograd.

Jonas, H., (1987), Technik, Medizin und Ethik. Zur Praxis des Prinzips Verantwortung, Insel Verlag, Frankfurt/M.

Jonas, H., (1978), „'On Faith, Reason and Responsibility“,Six Essays, Missoula, Montana, Scholars Press, Harper\& Row.

Касирер, Е., (1998), „Есеј за човекот: увод во филозофијата на човечката култура“, Култура, Скопје.

Kosik, K., (2007), „O dilemama suvremene povijesti“, Razlog, Zagreb.

Коцарев, Љ., (2021), „За планетата Земја, пандемијата на ковид-19 и Македонија“, во: „Нова Македонија“, вторник, 30 март 2021, Бр. 25.189, година LXXVI, (стр. 1-2).

Коцарев, Љ., (а), (2021), „Прочистување на просветувањето“, во: „Нова Македонија“" вторник, 20 април 2021, Бр. 25.207, година LXXVI, (стр. 2).

Lukács, G., (1977), „Povijest i klasna svijest: Studija o marksističkoj dijalektici“, Naprijed, Zagreb.

Lukač, G., (1966), „Razaranje uma“, Kultura, Beograd.

Мекинтаир, А., (1998), „По доблеста“, Табернакул, Скопје.

Milutinović, V., (2008), „Postideologije“, Utopija, Beograd.

Regenbogen,A.,/Meyer,U.,(hrsg.), (1998), Wörterbuch der philosophischen Begriffe, Felix Meiner Verlag, Hamburg,(43-44). 
Саркањац, Б., (1993), „Идеологијата и субјективитетот“, Метафорум, Скопје.

Свендсен, Л. Ф., (2010), „,Филозофија на стравот“, Ѓурѓa, Скопје, 2010 (ММХ).

Симоновска, С., (2006), „Етичките димензии на генетичкиот инженеринг“, во: Годишен зборник наФилозофскиот факултет, Annuaire Книга 59 Volume,Скопје, 2006, (669-678).

Симоновска, С.,/Петковска, Н., (2019), „'Новата' глобална поделба на трудот промислена низ призмата наРодот и класните раздики: текстилната индустрија и затворскиот труд“, во: Годишен зборник/ Annuaire, Книга 72 Volume, Филозофски Факултет на Универзитетот „Св. Кирил и Методиј“, Скопје, 2019, (543-554).

Симоновска, С.,/Скаловски, Д., (2012), „Етиката и родот - Прирачник - “, Филозофски факултет, Скопје.

Скаловски, Д., (2005), „Етика на одговорноста (Ханс Јонас)“, Bigoss, Скопје. Скаловски, Д., (2018), "Феномен(ологија) на медиумите“, Bigoss, Скопје.

Скаловски, А., (2010), „Во прво лице еднина (мал личен културодошки речник) - Том 1, од Анг. до Култ. -“, Аз-Буки/Филозофски факултет, Скопје.

Скаловски, Д., (2019), „Исток - Запад версус Запад - Остаток“, во: Годишен зборник/Annuaire, Книга 72Volume, Филозофски Факултет на Универзитетот „Св. Кирил и Методиј“, Скопје, 2019, (567-577).

Skalovski, D., (2020), „Imati Planetu ili biti čovečanstvo“ (Erih From: 19001980-2020) - Kospekt -“, во: „ARHE“, časopis za filozofiju / journal of philosophy, godina XVII * 33/2020 / year XVII * 33/2020, Novi Sad, 2020, (стр. 65-83).

Стефановски, Г., (2002), „Собрани драми“, Табернакул, Скопје.

Стојанов, Т., (2020), “Антиисточни пропагандни центри против граѓаните на Македонија: Случајот на Левица”, Портал “Фактор", https://faktor. $\mathrm{mk} /$ antiistochni-propagandni-centri-protiv-gragjanite-na-makedonijasluchajot-na-levica, (Пристапено на 09.04.2020).

Ќулафкова, К., (прир.), (2007), „Поимник на книжевната теорија“, МАНУ, Скопје.

Filipović, V., (1989), „Filozofijski rječnik“, Nakladni zavod matice hrvatske, Zagreb.

Fritzhand,A.\&Donev, D., (2020), ,,Between ego(centr)ism and cooperation:Would people become moralydisengaged or more altruistic after the Covid - 19 pandemic?“, во: Woesler, M. \& Sass, H.M.(eds.), Practical Ethics - Studies: Medicine and Ethics in Times of Corona, Volume 47, LIT Verlag, Germany.

Fromm, E., (1980), „Imati ili biti?“, Naprijed, Zagreb.

Habermas, J., (1980), „Teorija i praksa“, Bigz, Beograd.

Habermas, J., (1975), ",Saznanje i interes“, Nolit, Beograd.

Хајлс, К., (2003) „Како станавме постлуѓе: виртуелните тела во кибернетиката, дитературата иинформатиката“, Тера Магика, Скопје. 
Honderich, T., (ed.), (1995), The Oxford Companion to PHILOSOPHY, Oxford New York, Oxford University Press, (270).

Honet, A.,(2019), Ideja socijalizma: Pokušaj osavremenjivanja,Akademska knjiga, Beograd.

Council on foreign relationas, (2021), „На човештвото му се заканува жед“, во: „Нова Македонија“, петок, 30 април - понеделник, 3 мај 2021, бр. 25.216, година LXXVI, (стр. 11/14).

Чипан, Б., (1986), „111 тези за архитектурата“, Македонска книга, Скопје. Џепароски, И., (прир.), (2007), „Аспекти на другоста: зборник по културологија“, Евро-Балкан Прес-Менора,Скопје.

Џепароски, И., (2008), „Естетика на возвишеното“, Магор, Скопје.

Џепароски, И., (2020), „Естетика: Естетички категории“, Аз-Буки, Скопје. Џепароски, И., (2000), „Отаде системот“, Култура, Скопје.

Џепароски, И., Djeparoski, I., (2018), „Човек - Натчовек - Трансчовек / Human-Superhuman - Transhuman“, во: Contex / Контекст 18, Review for Comparative Literature and Cultural Research / Списание за компаративна книжевност и културолошко истражување, Institute of Macedonian Literature / Институт за македонска дитаратура, Скопје, (7-17).

Honderich, T., (ed.), (1995), The Oxford Companion to PHILOSOPHY, Oxford New York, Oxford University Press, (270).

Honet, A.,(2019), Ideja socijalizma: Pokušaj osavremenjivanja,Akademska knjiga, Beograd.

Council on foreign relationas, (2021), „На човештвото му се заканува жед“, во: „Нова Македонија“, петок, 30 април - понеделник, 3 мај 2021, бр. 25.216, година LXXVI, (стр. 11/14).

Чипан, Б., (1986), „111 тези за архитектурата“, Македонска книга, Скопје. Џепароски, И., (прир.), (2007), „Аспекти на другоста: зборник по кудтурологија“, Евро-Балкан Прес-Менора, Скопје.

Џепароски, И., (2008), „Естетика на возвишеното“, Магор, Скопје.

Џепароски, И., (2020), „Естетика: Естетички категории“, Аз-Буки, Скопје. Џепароски, И., (2000), „Отаде системот“, Култура, Скопје.

Џепароски, И., Djeparoski, I., (2018), „Човек - Натчовек - Трансчовек / Human - Superhuman - Transhuman“,во: Contex / Контекст 18, Review for Comparative Literature and Cultural Research / Списание за компаративна книжевност и културолошко истражување, Institute of Macedonian Literature / Институт за македонска дитература, Скопје, (7 - 17). 